\title{
Evaluation of Phenotypic and Genotypic Characteristics of Carbapnemases- producing Enterobacteriaceae and Its Prevalence in a Referral Hospital in Tehran City
}

\author{
Kosar Jalalvand ${ }^{1}$, Nasrin Shayanfar ${ }^{1 *}$, Fereshteh Shahcheraghi², Elahe Amini ${ }^{3}$, \\ Mahsa Mohammadpour ${ }^{4}$, Pegah Babaheidarian'
}

\author{
Department of Pathology, Hazret-e-Rasoul Hospital, Iran University of Medical Sciences, Tehran, Iran \\ Department of Bacteriology, Pasteur Institute of Iran, Tehran, Iran \\ Skull Base Research Center, Hazret-e-Rasoul Hospital, The Five Senses Institute, Iran University of Medical Sciences, Tehran, Iran
}

Medical student, Tehran University of Medical Sciences, Tehran, Iran

\begin{tabular}{c}
\hline KEYWORDS \\
Enterobacteriacea, \\
drug resistance, \\
microbial, \\
polymerase chain reaction, \\
primer,DNA, \\
Gene \\
Scan to discover online \\
Q \\
Main Subjects: \\
Microbiology \\
\hline
\end{tabular}

Received 06 Aug 2019;

Accepted 23 Feb 2020;

Published Online 28 Feb 2020;

$\underline{10.30699 / i j p .2020 .111181 .2188}$ PMCID:

PMID:

\begin{abstract}
Background \& Objective: Carbapenem-resistant Enterobacteriaceae is a growing concern worldwide including Iran. The emergence of this pathogen is worrying as carbapenem is one of the 'last-line' antibiotics for treatment of infections caused by multi drug resistant gram- negative bacteria. The main objective of this study was to determine the prevalence of carbapenem-resistant Enterobacteriaceae in a referral hospital in Tehran, Iran.
\end{abstract}

\begin{abstract}
Methods: In this study, all positive isolates of Enterobacteriaceae recorded in blood, urine, and other body fluids were studied during April 2017 to April 2018 in a referral hospital in Tehran. All cases of resistance to carbapenems were first tested by modified Hodge test. All cases with positive or negative test, after gene extraction, were examined genotypically based on the primers designed for the three Klebsiella pneumoniae carbapenemase $(K P C)$, New Delhi metallo- $\beta$-lactamase $(N D M)$, and OXA-48 genes by conventional PCR method.
\end{abstract}

Results: 108 isolates (13.6\%) were resistant to all cephalosporins as well as to imipenem and meropenem. In a genotypic study, including 45 isolates, 13 isolates were positive for $O X A-48$ gene, 11 isolates for $O X A-48$ and $N D M$ genes, 11 isolates for $O X A$ 48, NDM and $K P C$ genes, 4 isolates for $O X A-48$ genes and $K P C, 3$ isolates for $N D M$, one isolate for $K P C$. On the other hand, two isolates were negative for all three genes examined.

Conclusion: $O X A-48$ gene was one of the most common genes resistant to carbapenems in Iran. According to studies, the prevalence of antibiotic resistance in Iran is rising dramatically, which reduces the choice of antibiotics to treat severe infections in the future.

$\begin{array}{ll}\text { Corresponding Information: } & \begin{array}{l}\text { Nasrin Shayanfar, Department of pathology, H } \\ \text { Tehran, Iran. Email: nasrin.shayanfar@gmail.com }\end{array}\end{array}$

Copyright $\odot$ 2020. This is an open-access article distributed under the terms of the Creative Commons Attribution- 4.0 International License which permits Share, copy and redistribution of the material in any medium or format or adapt, remix, transform, and build upon the material for any purpose, even commercially.

\section{Introduction}

Emergence of carbapenem-resistant Enterobacteriaceae is being reported increasingly worldwide and is becoming an important issue in health care systems (1).

Nosocomial infections, a major public healthcare problem, are more prevalent in developed countries because of the related mortality and socioeconomic costs (2). Enterobacteriaceae is one of the major causative agents of nosocomial infections $(3,4)$.

Gram-negative bacteria of the Enterobacteriaceae family are important causes of urinary tract infections (UTIs), bloodstream infections, hospital- and healthcare-associated pneumonias, and various intraabdominal infections (5).
Emerging resistance in Enterobacteriaceae is a significant problem which requires immediate attention. (5).

The carbapenem group (e.g., imipenem, meropenem) is a safe and generally effective therapeutic choice for the treatment of severe gram-negative bacterial infections when resistance to other classes of antimicrobials is present (6). Due to their broadspectrum activity, these antibiotics are commonly used in the treatment of life-threatening infections. Excessive and inappropriate use of these drugs, has led to an increased resistance to carbapenems. This issue is one of the main causes of the expression of carbapenemase 
genes such as IMP, VIM, NDM, OXA-48, and KPC among the members of this family (7).

The production of acquired carbapenemase significantly limits the choice of antibiotic treatment infections caused by Gram-negative bacteria (8).

More seriously, Enterobacteriaceae with carbapenem-hydrolyzing-lactamases are an emerging problem (9). OXA-48 carbapenemase (Ambler class D) was first reported in Enterobacteriaceae in Turkey in $2001(10,11)$.

Subsequently, spread has been reported not only across Turkey but also in the Middle-East, North Africa, and Europe (12). The KPC constitutes the most common class A carbapenemase in Klebsiella pneumoniae which was first reported in 1996 in the USA, though current reports reveal their presence in Europe, Asia, and South America (13).

New Delhi Metallo-beta-lactamase was first reported in K. pneumonia and Escherichia coli isolated from a 59-year-old Swedish patient from India who was previously admitted to a hospital in New Delhi (14). The main objective of this study is to show the prevalence of carbapenem-resistant Enterobacteriaceae and to investigate the presence of carbapenemase genes in Enterobacteriaceae clinical isolates resistant to carbapenem antibiotics from hospitalized patients in a university referral hospital in Tehran, Iran.

\section{Materials and Methods \\ Clinical Isolates}

A total of 800 Enterobacteriaceae isolates were collected from various clinical specimens including urine $(n=473)$, tracheal aspirate $(n=19)$, broncho alveolar-lavage (BAL) fluid $(n=11)$, wound $(n=44)$, cerebrospinal fluid $(n=2)$, sputum $(n=78)$, catheter $(n=9)$, other sterile body fluid $(n=99)$, and blood ( $\mathrm{n}=63$ ) between April 2017 and April 2018 from hospitalized patients at Rasoul Akram hospital, one of the referral university hospitals of Tehran, Iran.

\section{Bacterial Isolation and Identification}

All samples were routinely cultured on MacConkey and blood agar plates. Blood samples were cultured in Blood culture bottles. The isolates were identified at the species level using standard biochemical tests and microbiological methods such as colony types, motility, carbohydrate fermentation of glucose, lactose and sucrose, Triple Sugar Iron (TSI), Simmons citrate, SIM (Sulfide, Indole,
Motility), Methyl Red, and urease. These are common biochemical tests used for identifying different species of Enterobacteriaceae (15).

\section{Antibiotic Susceptibility Test}

The tested antibiotics were amikacin and gentamicin (aminoglycosides); ampicillin-sulbactam, and piperacillin-tazobactam ( $\beta$-lactams); cephazolin, cefepime, cefotaxime, ceftazidime, (cephalosporins); ciprofloxacin (quinolone); Sulfamethoxazole / Trimethoprim; colistin (polymyxin), imipenem and meropenem (carbapenems) and Nitrofurantoin (in urinary infection) (MAST company, Germany). They were investigated using the disc-diffusion method as described in Clinical and Laboratory Standards Institute (CLSI) guidelines (16). We used E. coli ATCC 25922 as a carbapenem-susceptible strain, and K. pneumoniae AO 8053 as a carbapenem resistant for quality control. MIC to meropenem was determined by E-test strips (Liofilchem company, Italy), according to the manufacturer's instructions and CLSI 2015 guidelines. The isolates with MIC values $\geq 4 \mu \mathrm{g} / \mathrm{mL} ; 2 \mu \mathrm{g} / \mathrm{mL}$ and $\leq 1 \mu \mathrm{g} / \mathrm{mL}$ for meropenem were considered as resistant, intermediate, and susceptible, respectively (16).

Phenotypic determination of carbapenemases was performed using the modified Hodge test (MHT). The MHT was carried out according to CLSI guidelines using a $10 \mu \mathrm{g}$ disc of ertapenem on Muller-Hinton agar plates. Following overnight incubation, the presence of a "cloverleaf shaped" inhibition zone was interpreted as a positive result. E. coli ATCC 25922 was used as the carbapenem susceptible strain (17).

Molecular Detection of Genes Encoding Carbapenemases

Genomic DNA isolates was obtained from Entrobacteriaceae by boiling two or three colonies of each isolate in $500 \mathrm{~mL}$ of distilled water for $10 \mathrm{~min}$ and centrifugation at 10,000 rpm for $10 \mathrm{~min}$. The supernatant was used as a template for polymerase chain reaction (PCR) assay. PCR assays were carried out for detection of $K P C, N D M$, and $O X A-48$ genes using a set of specific primers as previously described (Table 1) $(2,18-21)$. Standard strains for blaOXA-48, blaNDM, and blaKPC genes were provided by the Pasteur Institute of Iran. The study was approved by the ethics committee of the Iran University of Medical Sciences with the (code: IR.IUMS.FMD.REC.1396.9411100003 ).

Table 1. The sequencing primers used in this study

\begin{tabular}{ccccc}
\hline \multirow{2}{*}{ Gene } & $\mathbf{3}^{\prime}-\mathbf{5}^{\prime}$ Primer & Product size (bp) & Annealing Temperature $\left({ }^{\circ} \mathbf{C}\right)$ & References \\
\hline$K P C-F m$ & CGTCTAGTTCTGCTGTCTTG & 798 & 60 & $(2)$ \\
\hline$K P C-R m$ & CTTGTCATCCTTGTTAGGCG & 60 & $(2)$ \\
\hline$N D M-F$ & GGTTTGGCGATCTGGTTTC & 621 & 55 & $(2)$ \\
\hline$N D M-R$ & CGGAATGGCTCATCACGATC & & 55 & $(2)$ \\
\hline$O X A-48-F$ & GCGTGGTTAAGGATGAACAC & 438 & 55 & $(2)$ \\
\hline$O X A-48-R$ & CATCAAGTTCAACCCAACCG & & 55 & \\
\hline
\end{tabular}




\section{Statistical Analysis}

Data was presented as mean and standard deviation for quantitative variables, and percentage for qualitative variables. The correlation between the variables was assessed by Pearson correlation test. Mann-Whitney U test or t-test was applied to compare quantitative variables. SPSS 22 (IBM Corp., Armonk, NY, USA) was used to analyze the statistical variables. P-values less than 0.05 were set as statistically significant level

\section{Results \\ Bacterial Isolates}

Here, $108(13.6 \%)$ of 800 Enterobacteriaceae isolates (481 E. coli, $291 \mathrm{~K}$. pneumoniae, 8 Enterobacter and 20 other Enterobacteriaceae) collected were carbapenem-resistant Enterobacteriaceae (CRE) consisting of $K$. pneumoniae $(\mathrm{n}=102)$, E. coli $(\mathrm{n}=4)$, and Enterobacter $(\mathrm{n}=2)$. Carbapenem-resistant was $35 \%$ in $K$. pneumoniae, $25 \%$ in Enterobacter and less than $1 \%$ in $E$. coli isolates.

A total of 72 isolates $(66.66 \%)$ were isolated from ICU wards, while the remaining isolates were recovered from other wards. The isolates were predominantly collected from sputum $(29 / 108 ; 27 \%)$, urine $(24 / 96$; $25 \%$ ), wound secretions $(10 / 108 ; 9.5 \%), \%)$, broncho alveolar lavage (BAL) $(9 / 108 ; 8.5 \%)$, catheter $(3 / 108$; $3 \%)$, tracheal secretions $(2 / 108 ; 1.85 \%)$, CSF $(1 / 108$; $1 \%)$, and other sites of isolation $(18 / 108 ; 16 \%)$. Most carbapenem-resistant $K$. pneumoniae isolates were obtained from respiratory specimens including sputum, tracheal secretions, and BAL $(39 / 102 ; 38 \%)$ and urine specimens $(22 / 102 ; 21.5 \%)$.

Both carbapenem-resistant Enterobacters were isolated from blood cultures, separated from the same ICU ward. Carbapenem-resistant $E$. coli were isolated from urine $(2 / 4 ; 50 \%)$, sputum $(1 / 4 ; 25 \%)$ and wound secretion $(1 / 4 ; 25 \%)$ specimen. Interestingly, three of the four isolates were found in the same ICU ward.

The age of patients ranged from 16 years to 91 years (mean $=58.53$ years). Male-to-female ratio was 1.66 and $59 \%$ of patients were over 60 years old. The isolates from intensive care units covered $67 \%$ of carbapenem-resistant Enterobacteriaceae, which included $100 \%$ of E. coli and Enterobacter but $65 \%$ of K. pneumoniae.

\section{Antimicrobial Susceptibility Testing}

Overall, all isolates were resistant to at least three classes of antibiotics and they were considered as MDR. The rates of resistance to imipenem and meropenem among isolates were 90\% (97/108) and
96.4\% (104/108), respectively. The percentages of resistance to other antimicrobial agents were as follows: colistin $5.5 \%$ (6/108); trimethoprim /sulfamethoxazole $80 \%$ (86/108); amikacin 89\% (96/108); and nitrofurantoin 71.5\% (17/24). All isolates demonstrated resistance to ceftazidime, cefepime, cefazolin, cefotaxime, ciprofloxacin, ampisulbactam-piperacillin.

Of the 45 carbapenem resistant entrobacteriaceae isolates, all were high-level meropenem-resistant (MIC $\geq 4$ ), except for 4 isolates. The lowest and highest level of meropenem MIC for carbapenem-resistant isolates were estimated $0.16 \mathrm{mg} / \mathrm{L}$ and $>32 \mathrm{mg} / \mathrm{L}$, respectively.

The results of MHT revealed that 33 of 45 carbapenemresistant isolates were carbapenemase producing ones.

\section{Detection of Carbapenemases}

Forty-five isolates were included in the molecular study as CRE. Overal, of these 45 CREs, 13 (28.88\%) harbored only the $O X A-48$ gene; $3(6.66 \%)$ carried only the NDM gene, and $1(2.22 \%)$ carried only the $K P C$ gene. Further, $11(24.44 \%)$ of these isolates coproduced the NDM and $O X A-48$ genes; $4(8.8 \%)$ coproduced the $O X A-48$ and $K P C$; and $11(24.44 \%)$ coproduced the NDM, OXA-48, and KPC genes. Two isolates were negative for all 3 genes. There was no statistical association between the source of infections and gene expression $(P=0.32)$. The results of tests performed in Carbapenem producing Enterobacteriaceae are summarized in Table 2. Figure 1 shows a PCR product of blaOXA-48 gene. The first column represents the ladder and the last two columns represent positive and negative controls.

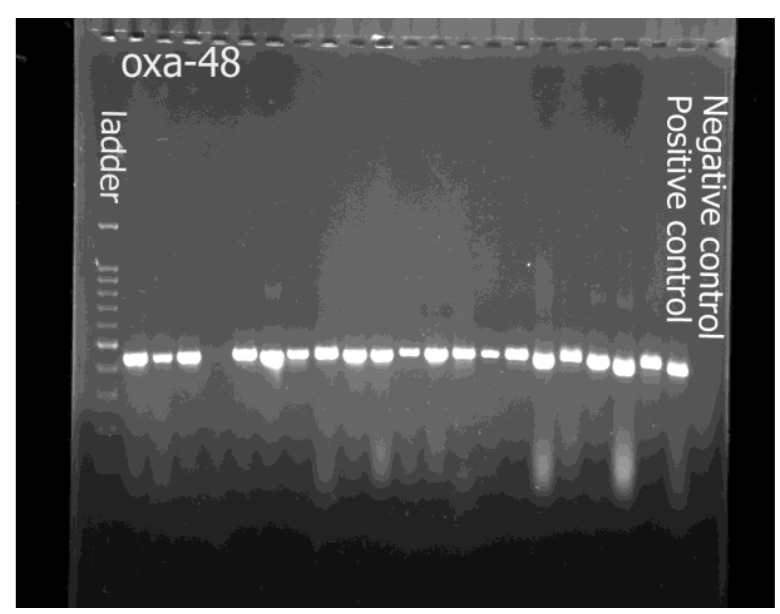

Fig.1. PCR product of blaOXA-48 gene. 
Table 2. Characteristics of carbapenem producing Enterobacteriaceae

\begin{tabular}{|c|c|c|c|c|c|c|c|}
\hline Isolates & Age/Gender & MIC & MHT & Genes & Ward & Specimen & Outcome \\
\hline $\begin{array}{c}1(K . \\
\text { pneumonia })\end{array}$ & 27/Female & $>32$ & positive & OXA48+NDM+KPC & SICU & Tracheal & Survived \\
\hline $\begin{array}{c}2(K . \\
\text { pneumonia })\end{array}$ & 67/Female & $>32$ & positive & OXA48+NDM1+KPC & ICU & tracheal & Died \\
\hline $\begin{array}{c}3(K . \\
\text { pneumonia })\end{array}$ & 54/Female & $>32$ & positive & OXA48+NDM+KPC & Post CCU & pancreas & Survived \\
\hline $\begin{array}{c}4(K . \\
\text { pneumonia })\end{array}$ & 56/Male & $>32$ & positive & OXA48+KPC & SICU & Sputum & Survived \\
\hline $\begin{array}{c}5(K . \\
\text { pneumonia })\end{array}$ & 68/Male & $>32$ & positive & OXA48+NDM+KPC & MICU & Sputum & Died \\
\hline $\begin{array}{c}6(K . \\
\text { pneumonia })\end{array}$ & 47/Male & $>32$ & positive & OXA48+NDM+KPC & Neuro ICU & Unknown & Died \\
\hline $\begin{array}{c}7(K . \\
\text { pneumonia })\end{array}$ & 62/Femal & $>32$ & positive & OXA48+NDM+KPC & SICU & Blood & Died \\
\hline $\begin{array}{c}8(K . \\
\text { pneumonia })\end{array}$ & 21/Femal & $>32$ & positive & NDM1 & Gynecology & Urine & Survived \\
\hline $\begin{array}{c}9(K . \\
\text { pneumonia })\end{array}$ & 78//Femal & $>32$ & positive & OXA48+NDM & MICU & Sputum & Died \\
\hline $\begin{array}{c}10(\text { K. } \\
\text { pneumonia })\end{array}$ & 80/Femal & $>32$ & positive & OXA48+NDM & MICU & Sputum & Died \\
\hline $\begin{array}{c}11(\mathrm{~K} . \\
\text { pneumonia })\end{array}$ & 65/Femal & $>32$ & positive & OXA48+NDM+KPC & MICU & Urine & Survived \\
\hline $\begin{array}{c}12(\mathrm{~K} . \\
\text { pneumonia })\end{array}$ & 23/Male & 12 & Negative & OXA48 & MICU & Sputum & Died \\
\hline $\begin{array}{c}13(\text { K. } \\
\text { pneumonia })\end{array}$ & 62/Male & $>32$ & Negative & Non & MICU & Sputum & Died \\
\hline $\begin{array}{c}14(\mathrm{~K} . \\
\text { pneumonia })\end{array}$ & 35/Male & $>32$ & positive & OXA48+NDM+KPC & ICU & CVP & Survived \\
\hline $\begin{array}{c}15(\mathrm{~K} . \\
\text { pneumonia })\end{array}$ & 72/Male & $>32$ & positive & OXA48+NDM+KPC & MICU & Sputum & Died \\
\hline $\begin{array}{c}16(\text { K. } \\
\text { pneumonia })\end{array}$ & 56/Male & $>32$ & positive & OXA48+NDM & SICU & $\begin{array}{l}\text { Wound } \\
\text { secretion }\end{array}$ & Died \\
\hline $\begin{array}{c}17(\mathrm{~K} . \\
\text { pneumonia })\end{array}$ & 55/Male & $>32$ & Negative & Non & MICU & Sputum & Died \\
\hline $\begin{array}{c}18(\text { K. } \\
\text { pneumonia })\end{array}$ & 64/Male & $>32$ & positive & OXA48+NDM & MICU & Sputum & Survived \\
\hline 19(Entrobacter) & 73/Male & $>32$ & positive & OXA48+NDM & ICU & Blood & Died \\
\hline $\begin{array}{c}20(\text { K. } \\
\text { pneumonia })\end{array}$ & 62/Male & $>32$ & positive & OXA48+NDM+KPC & MICU & Urine & Died \\
\hline $\begin{array}{c}21(\mathrm{~K} . \\
\text { pneumonia })\end{array}$ & 50/Male & 0.16 & positive & OXA48 & SICU & $\begin{array}{l}\text { Wound } \\
\text { secretion }\end{array}$ & Survived \\
\hline 22(Entrobacter) & 71/Female & $>32$ & positive & OXA48+NDM & ICU & Blood & Died \\
\hline $\begin{array}{c}23(\text { K. } \\
\text { pneumonia })\end{array}$ & 60/Male & $>32$ & positive & OXA48+NDM+KPC & MICU & Blood & Died \\
\hline $\begin{array}{c}24(\text { K. } \\
\text { pneumonia })\end{array}$ & 73/Male & $>32$ & Negative & OXA48 & ICU & Sputum & Died \\
\hline $\begin{array}{c}25(\text { K. } \\
\text { pneumonia })\end{array}$ & 70/Female & $>32$ & Negative & OXA48 & ICU & Sputum & Died \\
\hline $\begin{array}{c}26(\text { K. } \\
\text { pneumonia })\end{array}$ & 84/Female & $>32$ & positive & OXA48 & Nephrology & Urine & Survived \\
\hline $\begin{array}{c}27(\text { K. } \\
\text { pneumonia })\end{array}$ & 46/Male & 0.16 & positive & OXA48 & Infectious & Catheter & Survived \\
\hline $\begin{array}{c}28(\text { K. } \\
\text { pneumonia })\end{array}$ & 56/Male & 0.16 & positive & OXA48 & SICU & $\begin{array}{l}\text { Wound } \\
\text { secretion }\end{array}$ & Died \\
\hline
\end{tabular}




\begin{tabular}{|c|c|c|c|c|c|c|c|}
\hline Isolates & Age/Gender & MIC & MHT & Genes & Ward & Specimen & Outcome \\
\hline $\begin{array}{c}29(K . \\
\text { pneumonia })\end{array}$ & 71/Female & 6 & Negative & OXA48 & MICU & Pleura Fluid & Died \\
\hline $\begin{array}{c}30(\text { K. } \\
\text { pneumonia })\end{array}$ & 75/Female & & positive & KPC & SICU & Ascites fluid & Died \\
\hline $31($ E. coli $)$ & 75/Male & 6 & Negative & OXA48 & Neuro ICU & Urine & Died \\
\hline $32($ E. coli) & 29/Male & 4 & positive & OXA48+KPC & Neuro ICU & Urine & Survived \\
\hline $\begin{array}{c}33(\mathrm{~K} . \\
\text { pneumonia) }\end{array}$ & 74/Female & 4 & positive & OXA48+KPC & SICU & Urine & Died \\
\hline $\begin{array}{c}34(\text { K. } \\
\text { pneumonia })\end{array}$ & 36/Female & 3 & Negative & OXA48 & Medical & Sputum & Survived \\
\hline $\begin{array}{c}35(K . \\
\text { pneumonia })\end{array}$ & 37/Male & 6 & Negative & OXA48 & ICU & Unknown & Died \\
\hline $\begin{array}{c}36(K . \\
\text { pneumonia })\end{array}$ & 67/Female & 4 & positive & OXA48+KPC & Surgery & $\begin{array}{l}\text { Wound } \\
\text { secretion }\end{array}$ & Survived \\
\hline $\begin{array}{c}37(K . \\
\text { pneumonia) }\end{array}$ & 50/Male & 4 & Negative & OXA48 & Infectious & $\begin{array}{l}\text { Wound } \\
\text { secretion }\end{array}$ & Survived \\
\hline $\begin{array}{c}38(K . \\
\text { pneumonia) }\end{array}$ & 40/Female & 32 & Negative & NDM & Neuro ICU & Sputum & Died \\
\hline $\begin{array}{c}39(\mathrm{~K} . \\
\text { pneumonia })\end{array}$ & 38/Male & 32 & Negative & NDM & MICU & Urine & Died \\
\hline $\begin{array}{c}40(\text { K. } \\
\text { pneumonia })\end{array}$ & 77/Male & 6 & positive & OXA48+NDM & ICU & Sputum & Died \\
\hline $\begin{array}{c}41(K . \\
\text { pneumonia })\end{array}$ & 84/Female & $>32$ & positive & OXA48+NDM & Nephrology & Urine & Died \\
\hline $\begin{array}{c}42(\text { K. } \\
\text { pneumonia })\end{array}$ & 89/Male & $>32$ & positive & OXA48+NDM & Medical & Urine & Survived \\
\hline $\begin{array}{c}43(K . \\
\text { pneumonia) }\end{array}$ & 61/Male & $>32$ & positive & OXA48+NDM & Medical & Urine & Survived \\
\hline $\begin{array}{c}44(K . \\
\text { pneumonia })\end{array}$ & 42/Male & $>32$ & positive & OXA48+NDM & Neuro ICU & Sputum & Died \\
\hline $\begin{array}{c}45(K . \\
\text { pneumonia) }\end{array}$ & 48/Male & $>32$ & positive & OXA48 & SICU & Unknown & Survived \\
\hline
\end{tabular}

\section{Discussion}

Antibiotic resistance, especially simultaneous resistance to multiple classes of antibiotics (multiresistance), is an increasing global problem. Gram-negative bacteria, in particular the Enterobacteriaceae, are adapted to exchanging genetic information and antibiotic resistance. In these organisms, this is often due to the acquisition of genes from a shared pool (22). Resistance to carbapenems amongst Enterobacteriaceae is usually mediated by transferable beta-lactamase enzymes. Due to frequent occurrence of other resistance genes on the same mobile genetic elements, strains producing carbapenemases are normally extensively drug resistant (23).

The emergence of carbapenemases in Enterobacteriaceae is of great concern as these provide a far more efficient and stable mechanism of resistance to carbapenems than combinations of an ESBL and impermeability. Bacteria carrying these resistance determinants are often resistant to other treatment options, due to the frequent co-acquisition of non-betalactam resistance genes located on the same mobile genetic elements. Further, acquired carbapenemases have the potential for sepsis $(23,24)$. Although the presence of CRE have repeatedly been documented, larger scale, systematic studies with molecular investigations are still few in Iran (25). The prevalence of CRE in 2017-2018 collected at Rasoul Akram hospital was $13.6 \%$ in general. Specifically, the prevalence of carbapenems resistance in $K$. pneumoniae was 35\%; in Enterobacter 25\%, and in $E$. coli less than $1 \%$. On the other hand, in Solgi et al.'s study in 2015-2016 done in Isfahan, prevalence of CPKP was $41.7 \%$ (20). In this study, two Enterobacter isolates were obtained from the same ICU ward and from blood culture of patients at the same time. Also their gene presence was identical. 3 out of 4 carbapenem-resistant $E$. coli cases were obtained from the same ICU ward. They were all isolated from urine samples. Their gene presence was also identical. All instances of carbapenem resistance Entrobacteriaceae in the MICU ward were $K$. pneumoniae, and their gene presence was also similar except for one. This demonstrates the importance of infection control in hospital wards. 
The highest number of clinical isolates was collected from the respiratory tract and in the MICU. The highest antibiotic resistance was observed for cephalosporins and carbapenems while the least resistance to colistin and trimethoprim/ sulfamethoxazole. In the present study, the rate of antibiotic resistance with some variation which may arise from the source of infections and geographical distribution was comparable with the previous reported studies in Iran $(18,20,26,27)$. The administration of multiple antibiotics has been reported as a risk factor for carbapenem resistance acquisition (28). Findings by Patel et al. showed that carbapenem resistance is not attributed only to previous exposure to carbapenem but also exposure to other antibiotics (29). In our study, the ratio of male to female was 1.66, while in Kuwait, Arabian Peninsula, Malaysian studies, the male to female ratios were $0.9,1.8$, and 1.2 , respectively. (3032). In our study, $52.77 \%$ of the resistant group died, which was significantly $(P=0.043)$ in contrast to the carbapenem-sensitive group, where only $12.87 \%$ died. In the Kuwait study, $71.42 \%$ of the patients survived while $28.57 \%$ died (30). Dautzenberg and co-workers have reported that patients colonized with carbapenem resistant Enterobacteriaceae have higher mortality rates as compared to non-colonized patients due to long hospitalization (33). These results are consistent with the results of our study. Risk factors for infection with carbapenemase- producing Enterobacteriaceae (CPE) include hospitalization (particularly in intensive care units), mechanical ventilation, indwelling catheters, comorbidities, transplantation, exposure to broadspectrum antibiotics and previous colonization with these strains (23). This may be the cause of higher mortality in this group and requires further investigation. Considering the frequency of isolates resistant to carbapenem, according to the hospitalization wards, in our study, $67 \%$ of isolates were isolated from intensive care units. Similarly, in Solgi's study in Isfahan, $77 \%$ of the cases were isolated from intensive care units (20). However, in the Malaysian study, the highest percentages were observed in the surgical ward $(25 \%)$ and internal ward (25\%), some of whom were also admitted to the intensive care unit (32).

Our data regarding strains collected in one of referral hospital in Tehran is in accordance with previous reports that the most common mechanism of carbapenem resistance in CRE isolates of Tehran are the production of $O X A-48$-like and NDM carbapenemases (20).

This study found $C P E$ with $O X A-48, N D M$ and $K P C$ genes together or alone, in a hospital in Tehran. The co-production of $O X A-48$ - and NDM; OXA-48 and $K P C$ with $N D M$-producing $K$. pneumoniae has been reported in some Asian and European countries (3032,34-36). Beyond the dominance of $O X A-48$-like and NDM producing strains, it was also notable that almost half of the collection co-produced these two enzymes. Although, dual carbapenemase producing $K$. pneumoniae were encountered in Iran earlier (20). Their occurrence with such frequency has not been noted yet. To the best of our knowledge, this report presented the first identification of $O X A-48$ and $K P C$ with $N D M$-producing $K$. pneumoniae in Iran.

Genes of the $O X A-48$ type and related OXA enzymes have been found to be widely prevalent in North Africa, the Middle East, and the Indian subcontinent (12). And, more importantly, large numbers of outbreaks have occurred in regions such as Europe and Australia, where CRE is not endemic, as a result of international transfer of patients $(12,37)$. The first report of $O X A-48$ gene in Iran was by Azimi et al. in Tehran 2014, in 27 carbapenem-resistant $K$. pneumoniae isolates recovered from burn patients (1). It was subsequently re-identified in Iran $(20,27)$. The widespread prevalence of $O X A-48$-positive carbapenem resistant $K$. pneumoniae strains has been reported in several Asian and European countries including Turkey, Saudi Arabia, Taiwan, China, Russia and France which has become an expanding problem $(11,32,38-42)$.

A majority of $N D M$ cases reported worldwide were related to travel or hospitalization in the Indian subcontinent such as India and Pakistan (9). However, in our study, the NDM positive patient had no record of prior travel outside Iran. The presence of blaNDM without any association with international travel has also been reported by Rimrang and coworkers (43) which indicated that the NDM gene was acquired locally. The first report on the detection of NDM in Iran was by Shahcheraghi et al. in 2012 during a study on Enterobacteriaceae family isolates collected from five hospitals in Tehran (18). NDM was also reported by Fazeli and Solgi et al. (44,45). KPC is endemic in northeastern regions in the USA, Greece and Israel but cross regional spreading into United Kingdom, Brazil, Sweden, India and China had been reported recently (46). The first report of $K P C$ in Iran was made by Nobari and his colleagues in 2012 (21). This gene is often detected on mobile genetic elements such as plasmids and transposons which facilitates its rapid dissemination worldwide (47).

Regarding the prevalence of carbapenemase resistant genes in our study, the most frequent genes were $O X A-48$ in 13 cases $(28.88 \%)$, co-produced $O X A$ 48 and $N D M$ in 11 cases $(24.44 \%)$, simultaneous expression of co-produced NDM, $O X A-48$, and $K P C$ In 11 cases (24.44\%), co-produced $O X A-48$ and $K P C$ in 4 cases $(8.88 \%), N D M$ in 3 cases $(6.66 \%)$, and $K P C$ in one case $(2.2 \%)$, revealing that the highest frequency belonged to $O X A-48$. OXA-48 (58.3\%) and the coproduced $O X A-48$ and $N D M$ in $35.4 \%$ of cases have been reported in Solgi's study in Isfahan. However, no case of $K P C$ was reported (20). Only clinical isolates were included in our study whereas the study By Solgi et al. was focused on rectal swabs (48). OXA-48 expression in $37.5 \%$ of cases and co-produced $O X A-48$ and $K P C$ were also found in $37.5 \%$ of cases, with one case harboring KPC gene in the Malaysian study (32). 
However, in the Arabian Peninsula, the NDM gene was found in $46.5 \%$ of cases and $O X A-48$ in $32.5 \%$ of cases while their co-produced version was reported in $3.5 \%$ of cases (31). In the Kuwait study, NDM gene was reported in $57.1 \%$ of isolated and the co-produced version of the three genes and that of $N D M$ and $O X A$ 48 was reported in $33.33 \%$ and $9.52 \%$ of cases, respectively (30). Based on Solgi's study, they found that intestinal carriage rates of $N D M$ and $O X A-48$ producing Enterobacteriaceae are high, suggesting that NDM and OXA-48 have become endemic (48). Additionally, recent observations in neighboring countries, such as Kuwait (49) and Lebanon (50), indicates the emergence of this resistance mechanism in the Middle East. We could not find any of the targeted genes in the 2 carbapenem-resistant isolates, so their resistance to carbapenems may be due to other mechanisms including production of extendedspectrum beta-lactamases (ESBLs), AmpC betalactamases, decreased permeability of outer membrane or efflux pumps activity, or probably the presence of other genes that were not studied in this research (51) .Concurrent presence of carbapenemic genes in bacteria causes many concerns for physicians in the hospital as they cause hydrolysis of all $\beta$-lactam antibiotics as an important treatment option. Furthermore, the transfer of these genes among carriers and patients admitted in hospital increases the prevalence of the disease, which is difficult to control (52,53).

This study is limited by its small sample size as it only includes the carbapenem resistant Entrobacteriacae which were isolated during a 12 months period. Thus, the findings cannot be generalized to a broader population based on this study alone as it may include potential biases. A further limitation of our study is the high number of unknown or missing values in the analysis of potential risk factors. This reflects the difficulty to obtain information such as, previous hospitalization and travel history since microbiological laboratories often have no direct access to these data.

The present study suggested that the isolates of carbapenemase-producing Enterobacteriaceae have a high prevalence in patients admitted to our hospital. The presence of these genes upon transference of one strain to another strain, rapid detection of carbapenemase-producing isolates in clinical specimens, as well as rapid and accurate screening of patient carriers at the first stage of admission to hospitals to prevent dissemination of these strains are very important at the both hospital and community level. Undoubtedly, the emergence and release of these genes in the future will reduce the choice of antibiotics suitable for the treatment of severe infections. Ultimately, this will seriously threat the human health and healthcare system of the country. Therefore, it is imperative that a continuous monitoring system and strong programs to control the hospital infection should be used to prevent further dissemination in health centers and in the community. Otherwise, one of the biggest problems we face in the future is the loss of an important antibiotic treatment line, carbapenem, an increase in mortality rates, and an increase in the cost of treatment.

\section{Acknowledgements}

We thank professor Shahcheraghi for providing us the blaKPC; blaNDM and blaOXA48-positive controls. We would like to appreciate the department of microbiology of Pasteur Institute of Iran for helping us in molecular techniques. This work was funded by research grants from the Iran University of Medical Sciences (Project No.1428).

\section{Conflict of Interest}

The authors declared that there is no conflict of interest regarding the publication of this article.

\section{References}

1. Azimi L, Nordmann P, Lari AR, Bonnin RA. First report of OXA-48-producing Klebsiella pneumoniae strains in Iran. GMS Hyg Infect Control [Internet]. 2014;9(1):Doc07.

2. Shahcheraghi F, Aslani MM, Mahmoudi H, Karimitabar Z, Solgi H, Bahador A, et al. Molecular study of carbapenemase genes in clinical isolates of Enterobacteriaceae resistant to carbapenems and determining their clonal relationship using pulsed-field gel electrophoresis. J Med Microbiol [Internet]. 2017 May 1;66(5):570-6. [DOI:10.1099/jmm.0.000467] [PMID]

3. Dortet L, Poirel L, Nordmann P. Worldwide Dissemination of the NDM-Type Carbapenemases in Gram-Negative Bacteria. Biomed Res Int [Internet]. 2014;2014:1-12. [DOI:10.1155/2014/249856] [PMID] [PMCID]

4. Hidron AI, Edwards JR, Patel J, Horan TC, Sievert DM, Pollock DA, et al. Antimicrobial-Resistant Pathogens Associated With Healthcare-Associated Infections: Annual Summary of Data Reported to the National Healthcare Safety Network at the Centers for Disease Control and Prevention, 2006-2007. Infect Control Hosp Epidemiol [Internet]. 2008 Nov 2;29(11):996-1011. [DOI: 10.1086/591861] [PMID]

5. Paterson DL. Resistance in Gram-Negative Bacteria: Enterobacteriaceae. Am J Med [Internet]. 2006 Jun;119(6):S20-8. Available from: http://linkinghub.elsevier.com/retrieve/pii/S0002934306 003445 [DOI:10.1016/j.amjmed.2006.03.013] [PMID]

6. MCKIBBEN L, HORAN T, TOKARS J, FOWLER G, CARDO D, PEARSON M, et al. Guidance on Public Reporting of Healthcare-Associated Infections: Recommendations of the Healthcare Infection Control Practices Advisory Committee. Am J Infect Control [Internet]. $2005 \quad$ May;33(4):217-26. [DOI:10.1016/j.ajic.2005.04.001] [PMID]

7. Patel JB, Rasheed JK, Kitchel B. Carbapenemases in Enterobacteriaceae: Activity, Epidemiology, and 
Laboratory Detection. Clin Microbiol Newsl [Internet]. 2009 Apr 21;31(8):55-62. [DOI:10.1016/j.clinmicnews.2009.03.005]

8. Hrabák J, Chudáčkova E, Papagiannitsis CC. Detection of carbapenemases in Enterobacteriaceae: a challenge for diagnostic microbiological laboratories. Clin Microbiol Infect [Internet]. $2014 \quad$ Sep;20(9):839-53. [DOI:10.1111/1469-0691.12678] [PMID]

9. Woodford N, Johnson AP. Global spread of antibiotic resistance: the example of New Delhi metallo- $\beta$ lactamase (NDM)-mediated carbapenem resistance. J Med Microbiol [Internet]. 2013 Apr 1;62(4):499-513. [DOI:10.1099/jmm.0.052555-0] [PMID]

10. Poirel L, Heritier C, Tolun V, Nordmann P. Emergence of Oxacillinase-Mediated Resistance to Imipenem in Klebsiella pneumoniae. Antimicrob Agents Chemother [Internet]. $2004 \quad$ Jan 1;48(1):15-22. [DOI:10.1128/AAC.48.1.15-22.2004] [PMID] [PMCID]

11. Gülmez D, Woodford N, Palepou M-FI, Mushtaq S, Metan G, Yakupogullari Y, et al. Carbapenem-resistant Escherichia coli and Klebsiella pneumoniae isolates from Turkey with OXA-48-like carbapenemases and outer membrane protein loss. Int $\mathrm{J}$ Antimicrob Agents [Internet]. $2008 \quad$ Jun;31(6):523-6. [DOI:10.1016/j.ijantimicag.2008.01.017] [PMID]

12. Poirel L, Potron A, Nordmann P. OXA-48-like carbapenemases: the phantom menace. J Antimicrob Chemother [Internet]. 2012 Jul 1;67(7):1597-606. [DOI:10.1093/jac/dks 121] [PMID]

13. Munoz-Price LS, Quinn JP. The Spread of Klebsiella pneumoniae Carbapenemases: A Tale of Strains, Plasmids, and Transposons. Clin Infect Dis [Internet]. 2009 Dec;49(11):1739-41. [DOI:10.1086/648078] [PMID]

14. Poirel L, Revathi G, Bernabeu S, Nordmann P. Detection of NDM-1-producing Klebsiella pneumoniae in Kenya. Antimicrob Agents Chemother [Internet]. 2011 Feb;55(2):934-6. [DOI:10.1128/AAC.01247-10] [PMID] [PMCID]

15. Mahon CR, Lehman D, Manuselis Jr G. Textbook of Diagnostic Microbiology. 4th ed. 2014.

16. Institute $\mathrm{C}$ and LS. Performance Standards for Antimicrobial Susceptibility Testing; Twenty-Fifth Informational Supplement. CLSI document M100-S23. Wayne, PA 19087 USA; 2015.

17. Lee K, Chong Y, Shin HB, Kim YA, Yong D, Yum JH. Modified Hodge and EDTA-disk synergy tests to screen metallo-beta-lactamase-producing strains of Pseudomonas and Acinetobacter species. Clin Microbiol Infect [Internet]. $2001 \quad$ Feb;7(2):88-91. [DOI:10.1046/i.1469-0691.2001.00204.x] [PMID]

18. Shahcheraghi F, Nobari S, Rahmati Ghezelgeh F, Nasiri S, Owlia P, Nikbin VS, et al. First Report of New Delhi Metallo-Beta-Lactamase-1-Producing Klebsiella pneumoniae in Iran. Microb Drug Resist [Internet]. 2013 Feb;19(1):30-6. [DOI:10.1089/mdr.2012.0078] [PMID]

19. Poirel L, Walsh TR, Cuvillier V, Nordmann P. Multiplex PCR for detection of acquired carbapenemase genes. Diagn Microbiol Infect Dis [Internet]. 2011 May;70(1):119-23. [DOI:10.1016/j.diagmicrobio.2010.12.002] [MID]
20. Solgi H, Badmasti F, Giske CG, Aghamohammad S, Shahcheraghi F. Molecular epidemiology of NDM-1and OXA-48-producing Klebsiella pneumoniae in an Iranian hospital: clonal dissemination of ST11 and ST893. J Antimicrob Chemother [Internet]. 2018 Jun 1;73(6):1517-24. [DOI:10.1093/jac/dky081] [PMID]

21. Nobari S, Shahcheraghi F, Rahmati Ghezelgeh F, Valizadeh B. Molecular Characterization of Carbapenem-Resistant Strains of Klebsiella pneumoniae Isolated from Iranian Patients: First Identification of bla KPC Gene in Iran. Microb Drug Resist [Internet]. 2014 Aug;20(4):285-93. [DOI:10.1089/mdr.2013.0074] [PMID]

22. Partridge SR. Analysis of antibiotic resistance regions in Gram-negative bacteria. FEMS Microbiol Rev [Internet]. 2011 Sep;35(5):820-55. [DOI:10.1111/i.15746976.2011.00277.x] [PMID]

23. Tängdén T, Giske CG. Global dissemination of extensively drug-resistant carbapenemase-producing Enterobacteriaceae: clinical perspectives on detection, treatment and infection control. J Intern Med [Internet]. 2015 May;277(5):501-12. [DOI:10.1111/joim.12342] [PMID]

24. Thomas CP, Moore LSP, Elamin N, Doumith M, Zhang J, Maharjan S, et al. Early (2008-2010) hospital outbreak of Klebsiella pneumoniae producing OXA-48 carbapenemase in the UK. Int $J$ Antimicrob Agents [Internet]. $2013 \quad$ Dec;42(6):531-6. [DOI:10.1016/j.ijantimicag.2013.08.020] [PMID]

25. Zahedi Bialvaei A, Samadi Kafil H, Ebrahimzadeh Leylabadlo $\mathrm{H}$, Asgharzadeh $\mathrm{M}$, Aghazadeh $\mathrm{M}$. Dissemination of carbapenemases producing Gram negative bacteria in the Middle East. Iran J Microbiol [Internet]. 2015 Oct; 7(5):226-46.

26. Mansury D, Motamedifar M, Sarvari J, Shirazi B, Khaledi A. Antibiotic susceptibility pattern and identification of extended spectrum $\beta$-lactamases (ESBLs) in clinical isolates of Klebsiella pneumoniae from Shiraz, Iran. Iran J Microbiol [Internet]. 2016 Feb;8(1):55-61.

27. Hosseinzadeh Z, Sedigh Ebrahim-Saraie H, Sarvari J, Mardaneh J, Dehghani B, Rokni-Hosseini SMH, et al. Emerge of blaNDM-1 and blaOXA-48-like harboring carbapenem-resistant Klebsiella pneumoniae isolates from hospitalized patients in southwestern Iran. J Chin Med Assoc [Internet]. 2018 Jun;81(6):536-40. [DOI:10.1016/i.jcma.2017.08.015] [PMID]

28. Borer A, Saidel-Odes L. Limiting and controlling carbapenem-resistant Klebsiella pneumoniae. Infect Drug Resist [Internet]. 2013 Dec;9. Available from: http://www.dovepress.com/limiting-and-controllingcarbapenem-resistant-klebsiella-pneumoniae-peerreviewed-article-IDR [DOI:10.2147/IDR.S44358] [PMID] [PMCID]

29. Patel N, Harrington S, Dihmess A, Woo B, Masoud R, Martis $\mathrm{P}$, et al. Clinical epidemiology of carbapenemintermediate or -resistant Enterobacteriaceae. J Antimicrob Chemother [Internet]. 2011 Jul 1;66(7):1600-8. [DOI:10.1093/jac/dkr156] [PMID]

30. Jamal WY, Albert MJ, Khodakhast F, Poirel L, Rotimi VO. Emergence of New Sequence Type OXA-48 Carbapenemase-Producing Enterobacteriaceae in 
Kuwait. Microb Drug Resist [Internet]. 2015 Jun;21(3):329-34. Available from: http://www.ncbi.nlm.nih.gov/pubmed/25551428 [DOI:10.1089/mdr.2014.0123] [PMID]

31. Sonnevend Á, Ghazawi AA, Hashmey R, Jamal W, Rotimi VO, Shibl AM, et al. Characterization of Carbapenem-Resistant Enterobacteriaceae with High Rate of Autochthonous Transmission in the Arabian Peninsula. Cloeckaert A, editor. PLoS One [Internet] 2015 Jun 25;10(6):e0131372. [DOI:10.1371/journal.pone.0131372] [PMID] [PMCID]

32. Low Y-M, Yap PS-X, Abdul Jabar K, Ponnampalavanar S, Karunakaran R, Velayuthan R, et al. The emergence of carbapenem resistant Klebsiella pneumoniae in Malaysia: correlation between microbiological trends with host characteristics and clinical factors. Antimicrob Resist Infect Control [Internet]. 2017 Dec 7;6(1):5. [DOI:10.1186/s13756-016-0164-X] [PMID] [PMCID]

33. Dautzenberg MJD, Wekesa AN, Gniadkowski M, Antoniadou A, Giamarellou H, Petrikkos GL, et al. The Association Between Colonization With Carbapenemase-Producing Enterobacteriaceae and Overall ICU Mortality. Crit Care Med [Internet]. 2015 Jun;43(6):1170-7. [DOI:10.1097/CCM.0000000000001028] [PMID] [PMCID]

34. Brañas P, Villa J, Viedma E, Mingorance J, Orellana MA, Chaves F. Molecular epidemiology of carbapenemase-producing Klebsiella pneumoniae in a hospital in Madrid: Successful establishment of an OXA48 ST11 clone. Int J Antimicrob Agents [Internet]. 2015 Jul;46(1):111-6.

[DOI:10.1016/j.ijantimicag.2015.02.019] [PMID]

35. Guo L, An J, Ma Y, Ye L, Luo Y, Tao C, et al. Nosocomial Outbreak of OXA-48-Producing Klebsiella pneumoniae in a Chinese Hospital: Clonal Transmission of ST147 and ST383. Forestier C, editor. PLoS One [Internet]. $2016 \quad$ Aug 4;11(8):e0160754. [DOI:10.1371/journal.pone.0160754] [PMID] [PMCID]

36. Lixandru BE, Cotar AI, Straut M, Usein CR, Cristea D, Ciontea S, et al. Carbapenemase-Producing Klebsiella pneumoniae in Romania: A Six-Month Survey. Planet PJ, editor. PLoS One [Internet]. 2015 Nov 23;10(11):e0143214. Available from: http://dx.plos.org/10.1371/journal.pone.0143214 [DOI:10.1371/journal.pone.0143214] [PMID] [PMCID]

37. Espedido BA, Steen JA, Ziochos H, Grimmond SM, Cooper MA, Gosbell IB, et al. Whole Genome Sequence Analysis of the First Australian OXA-48-Producing Outbreak-Associated Klebsiella pneumoniae Isolates: The Resistome and In Vivo Evolution. Heimesaat MM, editor. PLoS One [Internet]. 2013 Mar 29;8(3):e59920. [DOI:10.1371/journal.pone.0059920] [PMID] [PMCID]

38. Kaase M, Schimanski S, Schiller R, Beyreiß B, Thürmer A, Steinmann J, et al. Multicentre investigation of carbapenemase-producing Escherichia coli and Klebsiella pneumoniae in German hospitals. Int J Med Microbiol [Internet]. 2016 Sep;306(6):415-20. [DOI:10.1016/j.ijmm.2016.05.009] [PMID]

39. Zowawi HM, Sartor AL, Balkhy HH, Walsh TR, Al Johani SM, AlJindan RY, et al. Molecular Characterization of Carbapenemase-Producing
Escherichia coli and Klebsiella pneumoniae in the Countries of the Gulf Cooperation Council: Dominance of OXA-48 and NDM Producers. Antimicrob Agents Chemother [Internet]. 2014 Jun;58(6):3085-90. [DOI:10.1128/AAC.02050-13] [PMID] [PMCID]

40. Tzouvelekis LS, Markogiannakis A, Psichogiou M, Tassios PT, Daikos GL. Carbapenemases in Klebsiella pneumoniae and other Enterobacteriaceae: an evolving crisis of global dimensions. Clin Microbiol Rev [Internet]. $2012 \quad$ Oct;25(4):682-707. [DOI:10.1128/CMR.05035-11] [PMID] [PMCID]

41. Ma L, Wang J-T, Wu T-L, Siu LK, Chuang Y-C, Lin JC, et al. Emergence of OXA-48-Producing Klebsiella pneumoniae in Taiwan. PLoS One [Internet]. 2015;10(9):e0139152. [DOI:10.1371/journal.pone.0139152] [PMID] [PMCID]

42. Fursova NK, Astashkin EI, Knyazeva AI, Kartsev NN, Leonova ES, Ershova ON, et al. The spread of bla OXA48 and bla OXA-244 carbapenemase genes among Klebsiella pneumoniae, Proteus mirabilis and Enterobacter spp. isolated in Moscow, Russia. Ann Clin Microbiol Antimicrob [Internet]. 2015 Dec 2;14(1):46. [DOI:10.1186/s12941-015-0108-y] [PMID] [PMCID]

43. Rimrang B, Chanawong A, Lulitanond A, Wilailuckana C, Charoensri N, Sribenjalux $P$, et al. Emergence of NDM-1- and IMP-14a-producing Enterobacteriaceae in Thailand. J Antimicrob Chemother [Internet]. 2012 Nov 1;67(11):2626-30. [DOI:10.1093/jac/dks267] [PMID]

44. Fazeli H, Norouzi-Barough M, Ahadi AM, Shokri D, Solgi H. Detection of New Delhi Metallo-BetaLactamase-1 (NDM-1) in carbapenem- resistant Klebsiella pneumoniae isolated from a university hospital in Iran. Hippokratia [Internet]. 2015;19(3):2059.

45. Solgi H, Giske CG, Badmasti F, Aghamohammad S, Havaei SA, Sabeti S, et al. Emergence of carbapenem resistant Escherichia coli isolates producing bla NDM and bla OXA-48 -like carried on IncA/C and IncL/M plasmids at two Iranian university hospitals. Infect Genet Evol [Internet]. $2017 \quad$ Nov;55:318-23. [DOI:10.1016/j.meegid.2017.10.003] [PMID]

46. Arnold RS, Thom KA, Sharma S, Phillips M, Kristie Johnson J, Morgan DJ. Emergence of Klebsiella pneumoniae Carbapenemase-Producing Bacteria. South Med J [Internet]. 2011 Jan;104(1):40-5. [DOI:10.1097/SMJ.0b013e3181fd7d5a] [PMID] [PMCID]

47. Nordmann P, Cuzon G, Naas T. The real threat of Klebsiella pneumoniae carbapenemase-producing bacteria. Lancet Infect Dis [Internet]. 2009 Apr;9(4):22836. [DOI:10.1016/S1473-3099(09)70054-4]

48. Solgi H, Badmasti F, Aminzadeh Z, Giske CG, Pourahmad M, Vaziri F, et al. Molecular characterization of intestinal carriage of carbapenem-resistant Enterobacteriaceae among inpatients at two Iranian university hospitals: first report of co-production of bla NDM-7 and bla OXA-48. Eur J Clin Microbiol Infect Dis [Internet]. $2017 \quad$ Nov 21;36(11):2127-35. [DOI:10.1007/s10096-017-3035-3] [PMID]

49. Jamal WY, Albert MJ, Rotimi VO. High Prevalence of New Delhi Metallo- $\beta$-Lactamase-1 (NDM-1) Producers among Carbapenem-Resistant Enterobacteriaceae in 
Kuwait. Galdiero M, editor. PLoS One [Internet]. 2016 Mar 31;11(3):e0152638. [DOI:10.1371/journal.pone.0152638] [PMID] [PMCID]

50. Dandachi I, Salem Sokhn E, Najem E, Azar E, Daoud Z. Carriage of beta-lactamase-producing Enterobacteriaceae among nursing home residents in north Lebanon. Int J Infect Dis [Internet]. 2016 Apr;45:24-31. [DOI:10.1016/j.ijid.2016.02.007] [PMID]

51. Meletis G, Exindari M, Vavatsi N, Sofianou D, Diza E. Mechanisms responsible for the emergence of carbapenem resistance in Pseudomonas aeruginosa. Hippokratia [Internet]. 2012 Oct;16(4):303-7.
52. Messaoudi A, Haenni M, Mansour W, Saras E, Bel Haj Khalifa A, Chaouch C, et al. ST147 NDM-1-producing Klebsiella pneumoniae spread in two Tunisian hospitals. J Antimicrob Chemother [Internet]. 2017;72(1):315-6. [DOI:10.1093/jac/dkw401] [PMID]

53. Seiffert SN, Marschall J, Perreten V, Carattoli A, Furrer $\mathrm{H}$, Endimiani A. Emergence of Klebsiella pneumoniae co-producing NDM-1, OXA-48, CTX-M-15, CMY-16, QnrA and ArmA in Switzerland. Int J Antimicrob Agents [Internet]. $2014 \quad$ Sep;44(3):260-2. [DOI:10.1016/j.ijantimicag.2014.05.008] [PMID]

\section{How to Cite This Article}

Jalalvand K. et al. Evaluation of Phenotypic and Genotypic Characteristics of Carbapenemases-producing Enterobacteriaceae and Its Prevalence in a Referral Hospital in Tehran City. Iranian Journal of Pathology, 2020; 15(2): 